\title{
Common Mistakes Found in Essay Writing of Chemical Engineering Department First Grade Students in Politeknik Negeri Lhokseumawe
}

\author{
Marlina Marzuki \\ Politeknik Negeri Lhokseumawe, Buketrata, Lhokseumawe, Aceh, Indonesia \\ marlina.marzuki78@gmail.com \\ *Corresponding Author \\ Whatsapp number: [08116803688]
}

How to Cite : Marzuki, M. (2019). Common Mistakes Found in Essay Writing of Chemical Engineering Department First Grade Students in Politeknik Negeri Lhokseumawe. International Journal for Educational and Vocational Studies, 1 (6), 591-594

\section{ARTICLE HISTORY}

Received: 18 July 2019

Revised: 23 August 2019

Accepted: 3 September 2019

\section{KEYWORDS}

Essay Writing;

Writing For Academic Purpose;

English As Foreign Language;;

\begin{abstract}
Many students often face difficulties when they are writing an essay in English while they are required to master written English as one of their basic competencies as the vocational students. The study observes common mistakes occurring in English essays written by first grade students of Oil and Gas Processing Study Program of Chemical Engineering Department in Politeknik Negeri Lhokseumawe, Aceh, Indonesia. The mistakes were categorized into seven types, i.e. word collocation and phrase, preposition, article/determiner, verb form, word order, spelling and punctuation. This research aims to find out the relation between the occurrences of the mistakes to the background of the students as the non-native English speaker. The methodology used in this study was combined between descriptive analysis and quantitative method. Data were analyzed by calculating the mistakes number done the students in their essays. The percentage of each mistake parameter is presented in pie chart form. Twenty-two students were involved in this study. Based on the result found in the study, the writer has gained several points that can be used to improve the teaching material for writing for academic purpose course. The study suggests that the course should focus on word collocation and some basic grammars instead of giving them English text.
\end{abstract}

This is an open access article under the CC-BY-SA license.

\section{INTRODUCTION}

English has been an international language and spoken widely around the world in many fields of business. The ability of mastery English is an absolute requisite for those who want to pursue education or work abroad (Harvard Business Review, 2012; van Weijen, D., 2012).

In addition, English lately becomes a basic core course in most level of education especially in higher education. It is a major course taught in a college. For this reason, college students are required to master at least written English in order to apprehend any literature served in English. Mastery English is also important for students to enrich their competency in competing with other students internationally. English language contains of four skills; listening, speaking, reading and writing. The speaking and writing skills made students able to communicate to others.

As non-native speaker, the ability of mastery oral and spoken English depends on learner's natural abilities and his/her effort in gaining knowledge and skill
(Abdulkareem, 2013). Different grammatical and lexical system from the mother tongue to English is also being a factor which contribute to one of major problem in learning English (Bitchener and Basturkmen, 2006). The same problems have also been found in Indonesia (e.g. Ariyanti, 2016; Ariyanti and Fitriana, 2017; Lestari, 2008; Husin \& Nurbayani, 2017; and Siahaan, 2013).

Writing is one of the English skills that should be learnt by students in order to be able to share their ideas in written forms. This capacity is one of the solutions for improving a better academic writing. Composing academic writing requires a considerable amount of language competence. The problems come when the language is being used as a non-native speaker. Writing skill is one of competencies must be acquired by Politeknik Negeri Lhokseumawe students, since they are expected to be able to report their laboratory projects in English. 
There are two points that should be understood by student in writing an essay, for instance. The students have to comprehend how to present the idea and to communicate the concept into a writing form. In the other hand, they are expected able to manage their writing tasks that include content, form, vocabulary, grammar, etc.

Based on experiences as a teacher in Politeknik Negeri Lhokseumawe, many students find some problems since they are non-native. Each language has a different structure, grammar, and styles. The students also have to select appropriate words in English which are mostly translated from their first language, such as Bahasa Indonesia. Inappropriate using words in writing may affect to loss of meaning. This research intended to observe some common mistakes done by the students in writing a simple essay in English.

\section{METHODS}

The writer conducted the research in her class in first grade student of Chemical Engineering department, especially in Oil and Gas Processing Study Program who are expected to master simple writing for academic purpose. The students were required to write an essay about their self and their goal within ten years in about $200-250$ words in narrative text. There were 22 essays analyzed in this study. As mentioned before, this study is aimed to categorize some common mistakes made by the students for then become main focus in designing and improving teaching material as well as teaching and learning process of English Writing for Academic purpose course.

\section{RESULTS AND DISCUSSIONS}

The finding of the study is displayed in Figure 1 presented in pie chart form. The whole students' mistakes were accumulated in percentage. Each type of mistake was ordered from the highest to the lowest number then evaluated based on its category. It is showed that the major mistakes in the study are word collocation phrase, verb form, punctuation, word order, preposition, article/determiner and spelling.

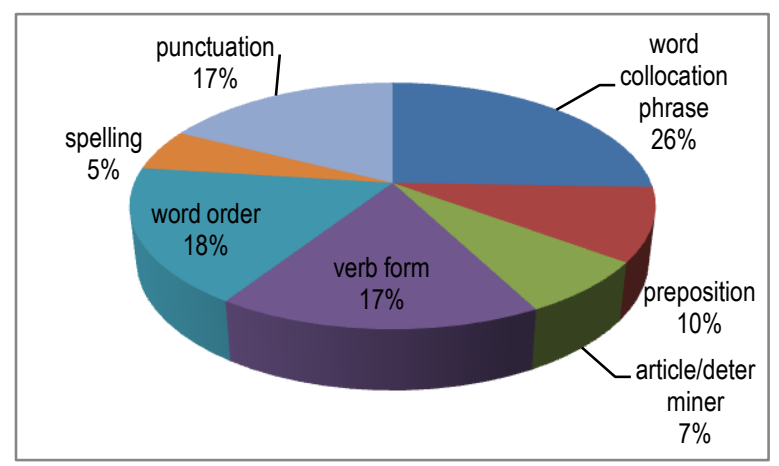

Figure1. Distribution of different error types (shown in percentage) of students' essays
Figure 1 showed that the most particular problem for the students in writing an essay is word collocation phrase and word order, while the less mistakes happen in spelling. The high frequency of the mistakes in word collocation phrase happens because the students choose inappropriate word to make a phrase. Table 1 shows some examples mistakes in word collocation phrase.

Table 1. Example Mistakes In Word Collocation Phrase

\begin{tabular}{cll}
\hline No. & \multicolumn{1}{c}{ Mistakes Found } & \multicolumn{1}{c}{ Revised } \\
\hline 1 & I make my homework every night & I do my homework every night \\
\hline 2 & I did mistakes in the class & I made mistakes in the class \\
\hline 3 & $\begin{array}{l}\text { I want to achieve much money after } \\
\text { college }\end{array}$ & $\begin{array}{l}\text { I want to make much money after } \\
\text { college }\end{array}$ \\
\hline
\end{tabular}

Those type of mistakes can be caused by lack of vocabularies. Furthermore, most of the time they did direct translate from Bahasa to English without knowing the appropriate collocation phrase. Based on the experience, this is the common problem found in the class during teaching learning process.

Word order errors on the other hand, occurred in some examples as shown in Table 2.

Table 2. Example Mistakes In Word Order Errors

\begin{tabular}{cll}
\hline No. & \multicolumn{1}{c}{ Mistakes Found } & \multicolumn{1}{c}{ Revised } \\
\hline 1 & I have nose flat & I have a flat nose \\
\hline 2 & My major is Engineering Chemical & My major is Chemical Engineering \\
\hline 3 & $\begin{array}{l}\text { I did often homework with my } \\
\text { friends }\end{array}$ & $\begin{array}{l}\text { I often did my homework with my } \\
\text { friends }\end{array}$ \\
\hline
\end{tabular}

Placing correct word order in English might become a problem for a non-native speaker because the different of grammatical rules in the language. For example; in Bahasa an adjective is placed after a noun while in English an adjective is placed before a noun.

The crucial mistakes in students' writing also occurred in verb from as shown in Table 3.

Table 3. Example mistakes in verb from

\begin{tabular}{cll}
\hline No. & \multicolumn{1}{c}{ Mistakes Found } & \multicolumn{1}{c}{ Revised } \\
\hline 1 & We can finished our study & We can finish our study \\
\hline 2 & The lab report collect daily & $\begin{array}{l}\text { The lab report should be collected } \\
\text { daily }\end{array}$ \\
\hline 3 & $\begin{array}{l}\text { My father want me to be an } \\
\text { engineer }\end{array}$ & $\begin{array}{l}\text { My father wants me to be an } \\
\text { engineer }\end{array}$ \\
\hline 4 & The class in our campus are cool & $\begin{array}{l}\text { The class in our campus is cool or } \\
\text { the classes in our campus are } \\
\text { cool }\end{array}$ \\
\hline
\end{tabular}

This kind of mistake occurred for some reasons such as there is no special verb/noun form in Bahasa that refers to singular or plural form specifically, as well as no specific verb form which relates to tenses.

Punctuation in writing is often ignored by some people which in this case may be the reason why the percentage of mistake is significant. In fact, punctuation help the reader to understand the writing then it cannot be separated from the writing itself. Table 4 shows mistakes in punctuation. 
Table 4. Example mistakes in punctuation

\begin{tabular}{lll}
\hline No. & Mistakes Found & Revised \\
\hline 1 & Its our favorite subject during this & $\begin{array}{l}\text { It's our favourite subject during } \\
\text { this semester }\end{array}$ \\
\hline 2 & Peomester & People asked me : "What is my \\
& goal ?" ? & goal?". \\
\hline 3 & I wanted to be an engineer but my & I wanted to be an engineer, but \\
& parents wanedt me to a doctor & $\begin{array}{l}\text { my parents wanted me to be a } \\
\text { doctor. }\end{array}$ \\
\hline
\end{tabular}

Preposition is in the fifth order of students' mistakes in writing essay. Table 5 shows some examples in preposition. Table 5. Example mistakes in preposition

\begin{tabular}{lll}
\hline No. & Mistakes found & Revised \\
\hline 1 & I go in the school & I go to the school \\
\hline 2 & Sometime we are going to home at & Sometime we were going home at \\
& 6 o'clock & 6 o'clock \\
\hline
\end{tabular}

The error of using preposition could be influenced by students' first mother tongue as well as lack of knowledge about how to use the appropriate prepositions in English.

Determiner/article mistakes does not quite often occur in the students' writing. It is quite reasonable because the material of article/ determiner is quite simple and the students can catch up the material easily. Additionally, the rule of using article is not as complicated as other material. The minor mistakes found in this type were in using article the for the definite noun. Some mistakes in determiner/article are shown in Table 6.

Table 6. Example mistakes in determiner/article

\begin{tabular}{lll}
\hline No. & Mistakes found & Revised \\
\hline 1 & $\begin{array}{l}\text { I was confused with material of } \\
\text { lecturer. Material is so difficult }\end{array}$ & $\begin{array}{l}\text { I was confused with material of } \\
\text { lecture. The material is so difficult }\end{array}$ \\
\hline 2 & $\begin{array}{l}\text { Politeknik Negeri Lhokseumawe is } \\
\text { an University in Buketrata }\end{array}$ & $\begin{array}{l}\text { Politeknik Negeri Lhokseumawe is } \\
\text { a university in Buketrata }\end{array}$ \\
\hline
\end{tabular}

The smallest percentage of mistake in this study is spelling. While writing, the students were encouraged to use the conventional dictionary. The purpose of using dictionary is to make the writing rich of vocabularies and to make the students used to the conventional dictionary. This contribute to less error in spelling and also the use of the word had varied. Nevertheless, teaching writing is not only focusing on how to write grammatically, but also how to organize, manage and express the ideas in a systimatical and critical way.

This reserach focuses on some commons mistake that are found in students' essay. As listed before, the biggest mistake happen in using word collocation/ word combinations. Word collocation is crucial in a writing which help the writer sharpen the idea. The literature provides insight about that errors concerning inappropraite use of collocations among all error types, have been experienced as the most commonly by non-native speakers (Gitsaki, 1999). A paucity of collocation proficiency is assosiated with lexical proficiency of the writer. This can explain why a non native speaker/writer are not able to use collocation as profiecient as native. The writer fails to correlate words on the basis of true and word partnership (Sung, 2003). In addition, lack of vocabularies also contribute in using wrong word collocation in this study.

While other mistakes found in students' essay mostly caused by direct translation from mother tongue to English, lack of vocabularies and also English grammatical rule is quite different from Bahasa.

Based on the experience in the class during teaching and learning process, beside of those weakness explained before, the motivation of student in writing is low as well as lack of respon during learning process. Teacher on the hand only lay on giving English Text and askes the students to rewrite the text in their own word. Teacher is expected to be more creative in choosing the material for teaching writing.

However, teacher effort is not the only way out in improving students' writing. Students are supposed to have more motivation and do practice continously. Students and actively ask the teacher about the material as well as have peer discussion with their colleagues.

\section{CONCLUSION}

Based on the result found in the study, it is showed that the major mistakes in the study are word collocation phrase, verb form, punctuation, word order, preposition, article/determiner and spelling. Those type of mistakes can be caused by lack of vocabularies direct translate from Bahasa to English without knowing the appropriate collocation phrase. The writer has gained several points that can be used to improve the teaching material for writing for academic purpose course. The study suggests that the course should focus on word collocation and some basic grammars instead of giving them English text. Beside the method used by the teacher should be more creative and interesting. Students are also expected to have more motivation in learning. They are also encouraged to have more references to enrich and improve their writing and be more careful in writing to avoid mirror mistakes such as using article and spelling.

\section{REFERENCES}

Abdulkareem, M. (2013). Investigation study of academic writing problems faced by Arab postgraduate students at Universiti Teknologi Malaysia (UTM). Theory and Practice in Language Studies, 3(9), 1552-1557.

Ariyanti, A. (2016). Shaping Students' Writing Skills Shaping Students' Writing Skills: The Study of Fundamental Aspects in Mastering Academic Writing. Indonesian Journal of EFL and Linguistics, 1(11), 2503-4197.

Ariyanti, A., \& Fitriana, R. (2017). EFL Students' Difficulties and Needs in Essay Writing. Advances in Social Science, Education and Humanities Research (ASSEHR), 158, 111-121.

Bitchener, J. \& Basturkmen, H. (2006). Perceptions of the difficulties of postgraduate L2 thesis students writing the discussion section. Journal of English for 
Academic Purposes. 5, 4-18.

Gitsaki, C. (1999). Second language lexical acquisition: A study o f the development of collocational knowledge. San Francisco: International Scholars Publications.

Husin, M. S. \& Nurbayani, E. (2017). The Ability of Indonesian EFL Learners in Writing Academic Papers. Dinamika Ilmu, 17 (2).

Harvard Business Review (2012) Global Business Speaks English, available online: https://hbr.org/2012/05/global-business-speaks-englis h.

Lestari, L. A. (2008). The Interactional Approach to the Teaching of Writing and Its Implications for Second Language Acquistion. TEFLIN Journal, 19(1).

Siahaan, J. (2013). An Analysis of Students' Ability and Difficulties in Writing Descriptive Texts. Journal of English and Education, 1(1), 114-121.

Sung, J. (2003). English Lexical Collocations and Their Relation to Spoken Fluency of Adult Nonnative Speakers. Pennsylvania: Indiana University of Pennsylvania.

van Weijen, D (2012) The Language of (Future) Scientific Communication, Research Trends, Issue 31. 